\title{
Africa
}

http://journals.cambridge.org/AFR

Additional services for Africa:

Email alerts: $\underline{\text { Click here }}$

Subscriptions: $\underline{\text { Click here }}$

Commercial reprints: $\underline{\text { Click here }}$

Terms of use : $\underline{\text { Click here }}$

MEYER (ed.), Aesthetic Formations: media, religion, and the senses. Basingstoke: Palgrave Macmillan (hb £60 - 978023060555 9; pb $£ 19.99-978023062229$ 6). 2010, 292 pp.

\section{TILO GRÄTZ}

Africa / Volume 82 / Issue 04 / November 2012, pp 663 - 665

DOI: 10.1017/S0001972012000599, Published online: 09 November 2012

Link to this article: http://journals.cambridge.org/abstract_S0001972012000599

How to cite this article:

TILO GRÄTZ (2012). Africa, 82, pp 663-665 doi:10.1017/S0001972012000599

Request Permissions : $\underline{\text { Click here }}$ 
impulse of cruel individuals but rather the performance of particular wider cultural and societal notions of masculinity that children themselves embody and inhabit in their everyday lives. They employ violence to condemn peers' misbehaviour and often to affirm themselves over others. However, this creates a contradictory balance between reciprocity and forms of street violence that becomes more problematic as her informants become young adults. Masculine violence is not only the practice of the street, but comes to be a practice of intergender relations, as sexual maturity and the societal expectations of adulthood complicate the picture.

Throughout her book, Heinonen tries to locate and discuss the social and cultural reality of street children within the broader society in which they live. Her analysis of the lives of street children in their families and on the street is interesting. However, her attempts at identifying a 'wider Ethiopian culture' to which both she, as an Ethiopian researcher, and her informants belong is problematic. The author engages with the notion of shame (yiluñnta), which she considers to be a feature of this wider Ethiopian culture. Yiluñnta consists of paying attention to what others may say or even think about one's own conduct in private or in public. Because people fear shame, they conform in order to avoid judgements and comments. The author comes to define this notion by quoting her interviews with Ethiopian scholars and lecturers and, finally, shows that her informants similarly knew and used this term. In this regard, this reviewer wonders whether existing social differences, for instance between street children themselves and middle-class intellectuals, might come to shape how shared cultural notions are used, managed and experienced. Hence, it might be said, Heinonen's cultural analysis of shame and her definition of a 'wider Ethiopian culture' open up an interesting methodological discussion on the relation between culture and practice, ethnographical analysis and cultural representation.

Such a tension between analysis and representation does not, however, call into question the broader contribution Heinonen makes to the literature on street children. Her work is an important start for an ethnography of the street, street dynamics and urban marginality - a contribution that the academic literature on Ethiopia has lacked until now.

\author{
MARCO DI NUNZIO \\ University of Oxford \\ marco.di-nunzio@wolfson.ox.ac.uk \\ doi:10.1017/S0001972012000587
}

BIRGIT MEYER (ed.), Aesthetic Formations: media, religion, and the senses. Basingstoke: Palgrave Macmillan (hb $£ 60$ - 978023060555 9; pb $£ 19.99$ - 978 023062229 6). 2010, 292 pp.

This volume focuses on the relationship between religion, media and the reconfiguration of religious groups in a globalizing world. In particular, it investigates media technologies (in a broader sense) that are appropriated by religious groups or movements and their devotees as means of communicating and promoting religious messages and conveying spiritual experiences. The collection, based on a collaborative research project, brings together studies on media usage of a wide range of religious communities in Latin America, the Caribbean, Europe, South Asia and Africa, and relates to a multitude of small and classic electronic media. All contributors follow the various processes of medialization of religious meaning as well as the transformation of practices of 
religious mediation by modern media. They demonstrate the role of media in both reconfiguring the respective groups and creating new 'sensational forms' and bonds to religion. In doing so, the volume provides a better understanding of religious attachments today as being shaped by changing technological and infrastructural environments, and explores the ways in which the use of new media technologies and formats strengthens the sensory dimension of religious practices.

In her introductory essay, Meyer is arguing against an image of religious groups as being distant from modern media because of their assumed conservative stance, and challenges the contrast often made between spiritual and technological spheres. On the contrary, religious groups are frontrunners in their use of up-to date media technologies. Furthermore, she aims at reconceptualizing religious congregations as 'aesthetic formations'. Meyer argues that the growing importance of electronic media for religious groups stands in a long line of mediating religious messages and the constant striving of religious actors to extend their appeal. Religion is per se contingent upon mediation, either in oral, scriptural, visual or digitally generated formats, and the experience of the transcendental - as an effect, for example, of aesthetically shaped and bodily felt mediation processes.

We are currently witnessing a shift towards new and stronger modes of bonding between members of religious communities, intricately linked to the incorporation of new media formats and their related aesthetics and particular expressive styles. Therefore, Meyer proposes the term aesthetic formations, referring by the latter term to the performative dimensions of those configurations that are constantly in the making, featuring neither fixed boundaries nor purely ideologically crafted contours. With regard to the first term, aesthetic formations, she is hinting at the experiential properties religious media offer in various environments in appealing to the (common) senses, thus creating shared emotions and particular kinds of relatedness and modes of bonding among believers. She convincingly conceptualizes the term aesthetic formation as being more appropriate and leading beyond the notion of communities, be they imagined or not. Cognitive imaginations alone, as Meyer argues, are ultimately never strong enough to bind adherents to the transcendental and a religious congregation. Imaginations and religious ideas must be symbolized, but also materialized, and need an experiential dimension to become 'real'. The study of aesthetic dimensions of religious mediations in this volume refers to a whole range of such sensory and bodily experiences - such as noise, smell, breath (de Abreu) and expressions aspects that have been rather neglected in studies on collective identities in recent decades.

The individual contributions to this very coherent collection are based on ethnographies and thick descriptions of mediated religious practices and their experiential dimensions in various local contexts. Part I of the volume addresses media-related modes and politics of bonding, pertinent to Candomblé groups in Bahia (van de Port) and Pentecostal believers in Rio de Janeiro (Oosterbaan) - both in Brazil - as well as representations of female bodies in Bengali films (Hoek). Part II investigates the positioning of religious ideas in wider public sphere(s), such as Tamil mythologies in popular films in Sri Lanka (Hughes) or Muslim reformist movements on the radio in northern Nigeria (Larkin), and elucidates the work of Rasta radio DJs on the (binational) island of Saint-Martin/Sint Maarten. Part III examines, under the cogent subheading mediating immediacy, the role of media technologies in enabling new religious experiences and conveying modes of spirituality (with regard to a Christian movement in Brazil studied by de Abreu), or a sense of divinity (de Witte, 
comparing a Pentecostal Church and Afrikania, a traditionalist cultural movement, both in Ghana), prophetic charisma (Machado, portraying the leader of the Raelian Movement in France) or moments of possession (Sánchez on Pentecostal squatter movements in Venezuela).

Given the outstanding ethnographic quality of all contributions and the theoretical scope of the volume, there is little to fault, although the reader in some cases misses a discussion of the particular potentials of the respective media technologies as agents in their own right, linking up with contemporary approaches from science and technology studies. In sum, the volume not only represents a fine collection of brilliant case studies and anthropological contributions to a renewed understanding of the ways in which religious congregations appropriate and shape contemporary media technologies, but also challenges established concepts of religious and political anthropology and helps to advance our theoretical and epistemological knowledge of contemporary religious processes. This exciting volume is of great importance for a wide range of readers from social sciences, cultural and religious studies, and philosophy, as well as media and communication studies.

\author{
TILO GRÄTZ \\ Freie Universität, Berlin \\ tilograetz@yahoo.de \\ doi:10.1017/S0001972012000599
}

FRANK GUNDERSON, Sukuma Labor Songs from Western Tanzania. Leiden: Brill (hb €94-978 900418468 8). 2010, 536 pp.

In African music scholarship, few scholars attempt to merge the methods of song collection and detailed ethnographic analysis into a single work. Song collection is a method of recording and documenting as many songs as possible to create an understanding about the cultural, historical and musical traditions of a given population. In contemporary scholarship, scholars mostly select samples of song collections and rarely print translations of an entire body of work. Ethnographic analysis is the more common method in current African music scholarship, where scholars conduct intensive fieldwork to understand a population or a cultural phenomenon.

Sukuma Labor Songs from Western Tanzania uses both methods to create an impressive study of the history and musical traditions of one Tanzanian ethnic group, the Sukuma. Frank Gunderson gathered, recorded and analysed hundreds of songs that provide historical, regional and cultural knowledge mostly focused on the theme of labour. At times, he relies on the work of those who, in the past, collected songs, including Carl Velten and Hans Cory. The bulk of the songs, however, are from Gunderson's own fieldwork among the Sukuma, a period of research that spans almost twenty years (1988-2006).

In addition to gathering these songs, Gunderson also set out to work with Sukuma musicians and other specialists on the meaning of the songs. Rather than search for a single interpretation, Gunderson allows each person to read or listen to the song and then provide comment. Over seventy people, many of whom are elders born between 1915 and 1950, provide interpretations of songs and music that appear in the collection. Gunderson argues that this approach reveals a great deal about both the person and the song itself. In describing the aim of the book, he writes: 'This is a polyvocal ethnography featuring song texts and discourse about song texts with no one interpreter, no one meaning, no complete or 